\title{
Kontribusi Bimbingan Belajar Dari Orang Tua Dan Motivasi Berprestasi Terhadap Kompetensi Pengetahuan IPS I Made Wahyu Ariyana ${ }^{1}, \mathrm{Ni}$ Nyoman Ganing ${ }^{2}$
}

\author{
${ }^{12}$ Prodi Pendidikan Guru Sekolah Dasar, FIP \\ Universitas Pendidikan Ganesha, Singaraja, Indonesia \\ e-mail:wahyuariyana19@gmail.com ${ }^{1}$, ninyoman.ganing@undiksha.ac.id ${ }^{2}$
}

\begin{abstract}
Abstrak
Penelitian ini bertujuan untuk mengetahui pengaruh yang signifikan Bimbingan Belajar orang tua dan motivasi berprestasi terhadap Kompetensi Pengetahuan IPS siswa kelas IV SD Gugus VII Mengwi, serta Bimbingan Belajar Dari Orang Tua dan Motivasi Berprestasi terhadap Kompetensi Pengetahuan IPS siswa kelas IV SD Gugus VII Mengwi. Pengambilan sampel dilakukan secara proporsional random sampling, didapat sampel sebanyak 117 orang. Teknik analisis adalah analisis regresi sederhana dan analisis regresi berganda. Hasil pengujian hipotesis pertama diperoleh $F_{\text {reg }}=115$. Pada taraf signifikansi $5 \% n=115$, maka diperoleh $F_{\text {tabel }}=3,92$. Dikarenakan $\mathrm{F}_{\text {reg }} 115>\mathrm{F}_{\text {tabel }}=3,92$ maka $\mathrm{H}_{0}$ ditolak dan disimpulkan bahwa terdapat pengaruh yang signifikan bimbingan belajar dari orang tua terhadap kompetensi pengetahuan IPS dengan kontribusi sebesar $12,25 \%$. Hasil pengujian hipotesis kedua diperoleh $\mathrm{F}_{\text {reg }}=115$. Pada taraf signifikansi $5 \% n=115$, maka diperoleh $F_{\text {tabel }}=3,92$. Dikarenakan $F_{\text {reg }} 115>F_{\text {tabel }}=3,92$ maka $H_{0}$ ditolak dan disimpulkan bahwa terdapat pengaruh yang signifikan motivasi berprestasi terhadap kompetensi pengetahuan IPS dengan kontribusi sebesar 19,36\%. Hasil pengujian hipotesis ketiga diperoleh $F_{\text {reg }}=17,81$. Pada taraf signifikansi $5 \% n=115$, maka diperoleh $F_{\text {tabel }}=3,08$. Dikarenakan $\mathrm{F}_{\text {reg }} 17,81>\mathrm{F}_{\text {tabel }}=3,08$ maka $\mathrm{H}_{0}$ ditolak dan disimpulkan bahwa terdapat pengaruh yang signifikan bimbingan belajar dari orang tua dan motivasi berprestasi terhadap kompetensi pengetahuan IPS dengan kontribusi sebesar $24,01 \%$.
\end{abstract}

Kata Kunci: bimbingan belajar, orang tua, motivasi berprestasi

\begin{abstract}
The aimed of this research was to know the significant effect of parents' tutoring and achievement motivation, on social studies competency on fourth grade elementary students of cluster VII in Mengwi, the significant effect, and the significant effect of both parents tutoring and achievement motivation on social studies competency on fourth grade elementary students of cluster VII in Mengwi. The sample was taken by proporsional random sampling technique and decided 117 students as the sample. Simple regression analysis and multiple regression analysis were used to analyze the data. The result of first hypotheses testing was $F_{\text {reg }}=115$. On the $5 \%$ of significance level, $n=115$, then obtained $F_{\text {table }}=3,92 . F_{\text {reg }} 115>F_{\text {table }}=3,92$. It meant that $H_{0}$ was rejected and concluded that there was a significant effect of parents tutoring on social studies competency with total of contribution was $12,25 \%$. The second hypotheses testing showed $F_{\text {reg }}=$ 115. On the $5 \%$ of significance level $n=115$, obtained $F_{\text {table }}=3$,92. It was seen that $F_{\text {reg }} 115>$ $F_{\text {tablel }}=3,92$, hence $H_{0}$ was rejected and concluded that there was a significant effect of achievement motivation on social studies competency with the contribution of $19,36 \%$. The third hypotheses testing was found $F_{\text {reg }}=17,81$. On the $5 \%$ of significance level $n=115$, obtained $F_{\text {table }}$ $=3,92$, obtained $F_{\text {table }}=3,08$. $F_{\text {reg }} 17,81>F_{\text {tablel }}=3,08$, so $H_{0}$ was rejected and the conclussion showed that there was a significant effect of parents tutoring and achievement motivation on social studies competency with the contribution of $24,01 \%$.
\end{abstract}

Keywords: parents' tutoring, achievement motivation, social studies competency

${ }^{*}$ Corresponding author.

Received 20 January 2020, Accepted 20 March 2020; Available online 5 Appril 2020 (C) 2020 MI All Rights Reserved 


\section{Pendahuluan}

Pendidikan merupakan aspek yang sangat penting dalam menghadapi era globalisasi yang penuh tantangan karena dengan pendidikan diharapkan mampu membentuk sumber daya manusia yang terampil, kreatif dan inovatif. Pendidikan merupakan kebutuhan bagi setiap manusia, karena dengan pendidikan segala potensi yang ada dalam diri manusia dapat tumbuh dan berkembang. Sehingga kemampuannya dapat dimanfaatkan untuk kepentingan diri dan juga untuk kepentingan orang lain. Seperti yang tercantum dalam Undang- Undang RI Nomor 20 Tahun 2003 tentang Sistem Pendidikan Nasional Bab I Pasal I Ayat I, dijelaskan bahwa :

"Pendidikan adalah usaha sadar dan terencana untuk mewujudkan suasana belajar dan proses pembelajaran agar peserta didik secara aktif mengembangkan potensi dirinya untuk memiliki kekuatan spiritual keagamaan, pengendalian diri, kepribadian, kecerdasan, akhlak mulia, dan keterampilan yang diperlukan dirinya, masyarakat, bangsa, dan negara"

Dengan pendidikan, manusia dapat belajar mencapai kemajuan dalam segala aspek kehidupan.Saat ini pendidikan di Indonesia belum sepenuhnya mecapai tujuan pendidikan yaitu mencerdaskan kehidupan bangsa. Untuk memajukan kualitas pendidikan pemerintah sudah melaksanakan berbagai upaya diantaranya yaitu pengembangan kurikulum, peningkatan kompetensi guru, peningkatan sarana dan prasarana. Selain upaya pemerintah diatas, kualitas sumber daya manusia juga berpengaruh terhadap kemajuan dunia pendidikan.

Lingkungan pendidikan atau tempat belajar dapat dibedakan menjadi lingkungan keluarga, lingkungan sekolah, dan lingkungan masyarakat. Anak pertama kali memperoleh pendidikan dari lingkungan keluarga. Hal ini dikarenakan lingkungan keluarga adalah lingkungan pertama tempat anak untuk mengembangkan diri. Segala aktivitas belajar selama 5 tahun pertama berjalan dalam keluarga. Bahkan setelah anak menginjak sekolah pun sebagian besar aktivitasnya berlangsung dalam keluarga, maka keluarga memiliki peran yang sangat penting bagi pertumbuhan dan perkembangan anak. "Pendidikan keluarga dikatakan sebagai peletak dasar pembentukan kepribadian anak"(Sujanto, 2014:8).

Dalam keluarga orang tua sangat berperan penting dalam proses pendidikan anaknya. Orang tua yang biasanya terdiri dari ayah dan ibu mempunyai tanggung jawab dalam memberikan pendidikan yang terbaik bagi anaknya. "Anak-anak, sebelum dapat bertangguang jawab sendiri, mereka masih sangat menggantungkan diri, masih meminta isi, bekal, cara bertindak terhadap sesuatu, cara berpikir, dan yang lainnya dari orang tuanya" (Sujanto, 2014:9). Orang tua dalam keluarga bertugas sebagai pendidik, pemelihara, pengasuh, pembimbing, pembina maupun guru bagi anaknya. Orang tua dapat disebut sebagai orang yang pertama bertanggung jawab atas kesejahteraan anaknya, atau orang yang harus mengutamakan kepentingan anaknya. Lebih lanjut peran orang tua dalam membimbing anaknya belajar di rumah adalah memberikan pendampingan pada saat anak belajar. Pendampingan secara langsung dalam membantu memahami materi pelajaran yang dipelajari, mendampingi anak dalam mengerjakan pekerjaan rumah yang diberikan oleh guru, atau pendampingan lain yang memberikan manfaat bagi pembelajaran anak. Perhatian dan bimbingan seperti di atas akan sangat berkesan pada anak sehingga semangat anak berprestasi lebih tinggi. Membudayakan belajar kepada anak tidak bisa dilakukan dalam waktu singkat tetapi memerlukan proses yang panjang. Pendidikan dalam lingkungan keluarga akan menjadi bekal bagi anak untuk tumbuh dan berkembang dalam lingkungan yang lebih luas yaitu lingkungan sekolah dan masyarakat.

Pada umumnya anak baru mulai sadar akan perlunya belajar setelah mereka mulai menempuh pendidikan di sekolah menengah, akan tetapi pada zaman sekarang ini mereka yang masih duduk di sekolah dasar diharapkan telah menyadari pentingnya belajar. Maka dari 
itu mereka perlu dibimbing dalam hal cara belajar yang baik, masalah penggunaan waktu, cara mencatat, berbagai cara mengatasi kesulitan belajar, cara belajar bersama, mengembangkan motivasi belajar dan lain-lain. Melalui pembiasaan, anak akan berlatih hingga secara tidak langsung ini akan membantu meningkatkan prestasi. Hal yang tak kalah pentingnya adalah stimulus dari dalam anak itu sendiri, yaitu motivasi anak untuk berprestasi. Orang tua harus membimbing dan memotivasi anak dalam belajar untuk meraih prestasi.

Motivasi adalah sesuatu yang menyebabkan orang melakukan sesuatu atau dorongan untuk bertindak. Motivasi bisa datang dari diri sendiri (faktor internal) dan juga bisa datang dari luar (faktor eksternal). "Namun pada hakikatnya motifasi itu timbul dari dalam diri sendiri, sedangkan faktor eksternal hanya bisa menjadi pendukung atau pemicu diri untuk termotivasi" (Sukini, 2016;17). Menurut Sumadi (dalam Djaali, 2008:101) "motivasi adalah keadaan yang terdapat dalam diri seseorang yang mendorongnya untuk melakukan aktivitas tertentu guna pencapaian suatu tujuan". Menurut Djaali, (2008:101) "motivasi adalah kondisi fisiologis dan psikologis yang terdapat dalam diri seseorang yang mendorongnya untuk melakukan aktivitas terntentu guna mencapai suatu tujuan". Dari uraian di atas dapat disimpulkan bahwa motivasi adalah dorongan dari diri sendiri maupun dari orang lain berupa dorongan fisik maupun non fisik yang sesuai dengan kebutuhan untuk melakukan aktivitas tertentu guna mencapai suatu tujuan.

Sehubungan dengan kebutuhan hidup manusia yang mendasari timbulnya motivasi, Maslow (dalam Djaali, 2008:101) "mengungkapkan bahwa kebutuhan dasar hidup manusia itu terbagi atas lima tingkatan, yaitu kebutuhan fisiologis, keamanan, sosial, harga diri, dan aktualisasi diri". Sementara McClelland (dalam Djaali, 2008:103) "mengemukakan bahwa diantara kebutuhan hidup manusia tertadapat tiga macam kebutuhan, yaitu kebutuhan untuk memproleh makanan, untuk berafiliasi, dan kebutuhan untuk berprestasi". Karena uraian ini berkaitan dengan faktor yang mempengaruhi belajar, maka konteks motivasi yang sesuai adalah motivasi berprestasi.

Motivasi berprestasi merupakan dorongan yang ada dalam diri anak untuk membuat dirinya berprestasi. Heckhausen (dalam Djaali, 2008:103) "mengemukakan bahwa motivasi berprestasi adalah suatu dorongan yang terdapat dalam diri peserta didik yang selalu berusaha atau berjuang untuk meningkatkan atau memelihara kemampuannya setinggi mungkin dalam semua aktivitas dengan menggunakan standar keunggulan". Motivasi berprestasi ini dapat dilihat dari antusiasme anak dalam mengikuti pelajaran, misalnya kedisiplinan di dalam kelas, kedisiplinan mengerjakan pekerjaan rumah, bertanya jika penjelasan guru kurang jelas, dan kerajinan peserta didik dalam mengerjakan soal latihan. Dua komponen tersebut yaitu bimbingan belajar orang tua dan motivasi berprestasi, jika dipadukan maka akan mendorong prestasi belajar anak.

Menurut Undang-Undang tentang Sistem Pendidikan Nasional Nomor 20 Tahun 2003 Pasal 37 Ayat 1, kurikulum pendidikan dasar dan menengah salah satunya wajib memuat mata pelajaran IImu Pengetahuan Sosial (IPS). IImu Pengetahuan Sosial (IPS) merupakan salah satu mata pelajaran yang diberikan mulai dari SD/MI/SDLB sampai SMP/MTs/SMPLB. IPS mengkaji seperangkat peristiwa, fakta, konsep, dan generalisasi yang berkaitan dengan isu sosial. Pada jenjang SD/MI mata pelajaran IPS memuat materi Geografi, Sejarah, Sosiologi, dan Ekonomi. Melalui mata pelajaran IPS, peserta didik diarahkan untuk dapat menjadi warga negara Indonesia yang demokratis, dan bertanggung jawab. Mata pelajaran IPS bertujuan agar peserta didik memiliki kemampuan yaitu: 1) Mengenal konsep-konsep yang berkaitan dengan kehidupan masyarakat dan lingkungannya, 2) Memiliki kemampuan dasar untuk berpikir logis dan kritis, rasa ingin tahu, inkuiri, dan memecahkan masalah dan keterampilan dalam kehidupan sosial, 3) Memiliki komitmen dan kesadaran terhadap nilai-nilai sosial dan kemanusiaan, 4) Memiliki kemampuan berkomunikasi, bekerjasama dan berkompetisi dalam masyarakat yang majemuk, di tingkat lokal, nasional dan global. Mata pelajaran IPS disusun 
secara sistematis, komprehensif, dan terpadu dalam proses pembelajaran menuju kedewasaan dan keberhasilan dalam kehidupan di masyarakat. Dalam setiap proses pembelajaran IPS diharapkan peserta didik dapat memperoleh hasil belajar yang optimal. Keberhasilan belajar sangat dipengaruhi oleh beberapa faktor. Faktor-faktor tersebut dapat dikelompokkan menjadi dua kelompok yaitu faktor dalam diri peserta didik (intern) dan faktor dari luar diri peserta didik (ekstern). Faktor dari dalam diri peserta didik yang berpengaruh terhadap hasil belajar diantaranya adalah kecakapan, minat, bakat, usaha, motivasi, perhatian, kelemahan dan kesehatan, serta kebiasaan peserta didik. Salah satu hal penting yang perlu ditanamkan dalam diri peserta didik bahwa belajar yang dilakukannya merupakan kebutuhan dirinya. Faktor dari luar diri peserta didik yang mempengaruhi hasil belajar diantaranya adalah lingkungan fisik dan nonfisik (termasuk suasana kelas dalam belajar, seperti riang gembira, menyenangkan), lingkungan sosial budaya, lingkungan keluarga, program sekolah (termasuk dukungan komite sekolah), guru, pelaksanaan pembelajaran, dan teman sekolah.

Berdasarkan hasil observasi yang dilakukan di SD Gugus VII Mengwi pada tanggal 30 November 2018 diperoleh informasi mengenai prestasi atau pencapaian kompetensi IPS peserta didik belum maksimal. Berdasarkan hasil wawancara dengan guru diperoleh informasi bahwa pengetahuan kompetensi IPS merupakan salah satu mata pelajaran yang membosankan, materi dalam mata pelajaran IPS yang cukup banyak menyebabkan peserta didik harus banyak menghafal, akan tetapi tidak semua peserta didik mempunyai kemampuan menghafal yang baik sehingga prestasi atau pencapaian kompetensi IPS belum maksimal. Kurangnya bimbingan belajar dari orang tua juga dikatakan salah satu penyebab dari tidak tercapainya prestasi atau pencapaian kompetensi IPS, karena sebagaian besar orang tua memberikan sepenuhnya tanggung jawab kepada pihak sekolah untuk memberikan pendidikan dan melupakan kewajibannya sebagai pendidik informal. Pernyataan tersebut dikatakan karena kurangnya pendampingan, bimbingan belajar, dan motivasi dari orang tua. Karena keterbatasan waktu orang tua sibuk bekerja menjadi alasan terbesar dalam membimbing dan mendidik anaknya sehingga melepas tanggung jawabnya dalam memperhatikan perkembangan anaknya. Selain itu motivasi anak dalam belajar juga belum maksimal, terlihat ketika wawancara dengan guru kelas dan diketahui masih banyak peserta didik yang malas belajar bahkan beberapa peserta didik tidak membuat pekerjaan rumah, karena kurangnya motivasi belajar dalam diri peserta didik mengatasi rintangan dalam belajar dan berupaya berbuat sesuatu dengan cepat dan baik. Perhatian, pendampingan, dan bimbingan dari orang tua juga menjadi alasan sehingga peserta didik tidak termotivasi dalam belajar dan mengerjakan pekerjaan rumahnya. Beberapa peserta didik pun mengatakan bahwa mereka tersebut memiliki orang tua yang sibuk bekerja sehingga ia tidak mendapat bimbingan belajar yang maksimal dari orang tuanya selama di rumah.

Penjelasan tersebut mengisyaratkan bahwa pembimbingan belajar dari orang tua kepada anak dan motivasi berprestasi disinyalir atau diperkirakan berkontribusi dalam menentukan prestasi belajar anak. Penulis merumuskan bahwa lingkungan yang paling dekat dengan anak adalah keluarga. Hal ini karena sebagian besar waktu anak dihabiskan di lingkungan keluarga. Oleh karena itu pada penelitian ini pembimbingan belajar dari orang tua kepada anak dan motivasi berprestasi disinyalir atau diperkiraan berkontribusi pada kompetensi pengetahuan IPS peserta didik kelas IV SD Gugus VII Mengwi Tahun 2018/2019.

Berdasarkan uraian tersebut, terasa sangat penting untuk mengkaji apakah terdapat kontribusi antara bimbingan belajar dari orang tua dan motivasi berprestasi siswa terhadap kompetensi pengetahuan IPS. 


\section{Metode}

Jenis penelitian ini adalah penelitian ex-postfacto. Penelitian ex-postfacto adalah suatu pendekatan pada subjek penelitian untuk meneliti yang telah dimiliki subjek penelitian secara wajar tanpa adanya usaha memberikan perlakuan (Dantes, 2012:59).

Penelitian ini dilakukan di SD Gugus VII Mengwi dengan sampel sebanyak 117 orang. Sampel dalam penelitian ini ditentukan dengan metode proporsional random sampling yaitu pemilihan sampel secara proporsional dari masing-masing sekolah yang tercakup dalam penelitian. Proporsional yang dimaksud dalam penelitian ini adalah penentuan jumlah sampel harus berimbang sesuai dengan jumlah siswa pada masing-masing sekolah.

Data yang diperlukan dalam penelitian ini diambil menggunakan metode non tes. Metode non tes digunakan untuk mengumpulkan data dari masing-masing variabel penelitian dalam bentuk angket/kuisioner untuk variabel bebas dan pencatatan dokumen untuk variabel terikat.

Pengukuran angket akan menggunakan skala likert yang mempunyai skor dari sangat positif sampai sangat negatif. Untuk menskor skala kategori Likert, jawaban diberi bobot dengan nilai kuantitatif 4, 3, 2, 1, untuk empat pilihan pernyataan positif, dan 1, 2, 3, 4 untuk pernyataan yang bersifat negatif.Penyusunan angket didasari oleh indikator-indikator yang telah disiapkan pada kedua variabel bebas.

Untuk menganalisis data yang telah berhasil dikumpulkan, telebih dahulu dianalisis dengan menggunakan statistik deskriptif sebelum dilanjutkan dengan statistik inferensial. Statistik deskriptif merupakan "statistik yang berkenaan dengan bagaimana cara mendeskripsikan,menggambarkan, menjabarkan atau menguraikan data sehingga mudah dipahami" (Siregar, 2017:2). Supardi (2016:3) juga memaparkan bahwa statistik deskriptif merupakan "bagian dari statistik yang mempelajari cara pengumpulan data dan penyajian data sehingga mudah dipahami". Berdasarkan dua pendapat tersebut dapat dirangkum bahwa statistik deskriptif merupakan metode statistik yang mempelajari cara pengumpulan dan penyajian data seperti mendeskripsikan, menggambarkan, data sehingga mudah dipahami. Statistik deskriptif dalam penelitian ini digunakan untuk mendeskripsikan data kompetensi pengetahuan matematika, peran orang tua dan motivasi belajar

Metode analisis data yang juga digunakan dalam penelitian ini adalah metode analisis kuantitatif dengan uji statistik. Statistik yang digunakan adalah statistik inferensial. "Statistik Inferensial (statistik induktif) merupakan statistik yang digunakan untuk menganalisis data sampel dan hasilya akan digeneralisasikan / diinferensikan kepada populasi dimana sampel itu diambil" (Dantes, 2016:1). Statistika inferensial dapat dibedakan menjadi dua yaitu statistika parametrik dan non parametrik.

Teknik analisis yang digunakan dalam penelitian ini adalah menggunakan uji prasyarat analisis dan uji hipotesis. Uji prasyarat terdiri dari uji normalitas, uji linieritas, uji multikolinearitas dan uji heterokedastisidas.

Uji normalitas yang digunakan adalah normalitas Kolmogorov-Smirnov. Uji Kolmogorov Smirnov digunakan untuk mengetahui kenormalan distribusi beberapa data. Uji linieritas ini digunakan untuk mengetahui apakah variabel bebas $(\mathrm{X})$ dan variabel terikat $(\mathrm{Y})$ memiliki hubungan linier atau tidak. Untuk mengetahui hal tersebut, variabel-variabel tersebut harus diuji keberartian dan linieritasnya.

Uji multikolinearitas juga dilakukan dalam rangka menguji apakah dalam model ganda ditemukan adanya korelasi antara variabel bebas. Dalam regresi yang baik disyaratkan tidak terjadi kolinearitas atau multikoleniaritas diantara variabel bebasnya" (Supardi, 2013: 157). Untuk mengetahui terjadinya kolineritas atau multikoleniaritas diantara variabel bebas dalam suatu model regresi dilakukan dengan melihat atau menguji nilai VIF (Variance Inflation Factor) atau nilai Tol (Tolerance). 
Uji Heterokedastisidas merupakan uji untuk mengetahui apakah dalam sebuah model regresi dalam penelitian, terjadi ketidaksamaan varian dari residual yang diamati. Menurut Ismail (2018:220) "apabila varian yang diamati bersifat tetap atau ajeg, keadaan ini disebut sebagai homokedastisidas. Sebaliknya jika varian yang diamati berubah dari satu pengamatan dengan pengamatan lain, kondisi data disebut heterokedastisidas". (Ismail, 2018). Uji statistik yang dapat digunakan untuk menguji heteroskedastisitas adalah uji Glejser berbantuan aplikasi Spss 21.0.

Pengujian hipotesis dilakukan melalui analisis regresi linier sederhana pada hipotesis I dan 2 dan regresi linier berganda pada hipotesis III dan untuk kontribusi dapat ditemukan melalui koefisien determinasi.

\section{Hasil dan Pembahasan}

Sebelum melakukan pengujian hipotesis, dapat dilakukannya pendeskripsian data, uji asumsi klasik terlebih dahulu yang meliputi uji normalitas, uji linieritas, uji multikolinieritas dan uji heterokesdastisidas.

Data yang dipaparkan dalam penelitian ini adalah data bimbingan belajar dari orang tua dan motivasi berprestasi sebagai variabel bebas (X) dan data kompetensi pengetahuan IPS sebagai variabel terikat $(\mathrm{Y})$.

Data tentang bimbingan belajar dari orang tua siswa kelas IV SD Gugus VII Mengwi tahun ajaran 2018/2019 yang dijadikan sebagai sampel penelitian sebanyak 117 orang. Data sampel penelitian disajikan dalam tabel distribusi frekuensi.

\section{Tabel 01}

Distribusi Frekuensi Hasil Skala Bimbingan Belajar Dari Orang Tua

\begin{tabular}{cc}
\hline Kelas Interval & Frekuensi $\left(\mathbf{f}_{\mathbf{i}}\right)$ \\
\hline $71-78$ & 3 \\
$79-86$ & 9 \\
$87-94$ & 22 \\
$95-102$ & 46 \\
$103-110$ & 22 \\
$111-118$ & 8 \\
$119-126$ & 4 \\
$127-134$ & 3 \\
\hline Jumlah & $\sum \mathbf{f}_{\mathbf{i}}=\mathbf{1 1 7}$ \\
\hline
\end{tabular}

Berdasarkan distribusi frekuensi tersebut, data yang diperoleh kemudian dianalisis untuk mengetahui mean, modus, dan median. Dari paparan data bimbingan belajar dari orang tua sampel penelitian terdapat 117 orang siswa dengan skor tertinggi adalah 129 dan skor terendah adalah 71. Dari sebaran data tersebut diperoleh mean adalah 99,39, modus adalah 98,5, dan median adalah 96,98.

Data tentang motivasi berprestasi siswa kelas IV SD Gugus VII Mengwi tahun ajaran 2018/2019 yang dijadikan sebagai sampel penelitian sebanyak 117 orang. Data sampel penelitian disajikan dalam tabel distribusi frekuensi. 


\section{Tabel 02}

Distribusi Frekuensi Hasil Skala Motivasi Berprestasi

\begin{tabular}{cc}
\hline Kelas Interval & Frekuensi $\left(\mathbf{f}_{\mathbf{i}}\right)$ \\
\hline $68-74$ & 4 \\
$75-81$ & 6 \\
$82-88$ & 16 \\
$89-95$ & 23 \\
$96-102$ & 23 \\
$103-109$ & 26 \\
$110-116$ & 13 \\
$117-123$ & 6 \\
Jumlah & $\sum \mathbf{f}_{\mathbf{i}}=\mathbf{1 1 7}$ \\
\hline
\end{tabular}

Berdasarkan distribusi frekuensi tersebut, data yang diperoleh kemudian dianalisis untuk mengetahui mean, modus, dan median. Dari paparan data motivasi berprestasi sampel penelitian terdapat 117 orang siswa dengan skor tertinggi adalah 118 dan skor terendah adalah 68. Dari sebaran data tersebut diperoleh mean adalah 97,86, modus adalah 103,83, dan median adalah 101,52.

Data tentang kompetensi pengetahuan IPS siswa kelas IV SD Gugus VII Mengwi tahun ajaran 2018/2019 yang dijadikan sebagai sampel penelitian sebanyak 117 orang diperoleh melalui pencatatan dokumen terhadap nilai UAS IPS siswa pada semester satu tahun pelajaran 2018/2019.

Data sampel penelitian disajikan dalam tabel distribusi frekuensi dengan langkah-langkah sebagai berikut.

Tabel 03

Distribusi Frekuensi Hasil Kompetensi Pengetahuan IPS

\begin{tabular}{cc}
\hline Kelas Interval & Frekuensi $\left(\mathbf{f}_{\mathbf{i}}\right)$ \\
\hline $71-73$ & 13 \\
$74-76$ & 27 \\
$77-79$ & 35 \\
$80-82$ & 19 \\
$83-85$ & 10 \\
$86-88$ & 8 \\
$89-91$ & 4 \\
$92-94$ & 1 \\
\hline Jumlah & $\sum \mathbf{f}_{\mathbf{i}}=\mathbf{1 1 7}$ \\
\hline
\end{tabular}

Berdasarkan distribusi frekuensi tersebut, data yang diperoleh kemudian dianalisis untuk mengetahui mean, modus, dan median. Dari paparan data motivasi berprestasi sampel penelitian terdapat 117 orang siswa dengan nilai tertinggi adalah 92 dan nilai terendah adalah 71. Dari sebaran data tersebut diperoleh mean adalah 78,79 , modus adalah 77,49 , dan median adalah 77,25 . Selanjutnya uji normalitas yang digunakan dalam penelitian ini adalah suatu uji untuk melihat residual sebaran data yang dimiliki berasal dari sebaran normal atau tidak (Cahyono, 2015: 19). Uji normalitas yang digunakan adalah menggunakan teknik Kolmogorov Smirnov dengan menguji nilai residual tiap variabel yaitu residual dari $\mathrm{X}_{1}$ terhadap $\mathrm{Y}, \mathrm{X}_{2}$ terhadap $\mathrm{Y}$ serta $\mathrm{X}_{1}$ dan $\mathrm{X}_{2}$ terhadap $\mathrm{Y}$. Uji normalitas nilai residu dianalisis dengan berbantuan aplikasi Microsoft Excel 2010. Berdasarkan hasil perhitungan, diperoleh nilai $\left|F_{\mathrm{T}}-\mathrm{F}_{\mathrm{S}}\right|$ maksimal pada data residual $\mathrm{X} 1$ terhadap $\mathrm{Y}$ adalah 0,018 . Selanjutnya yaitu membandingkan hasil $\mid \mathrm{F}_{\mathrm{T}^{-}}$ 
$\mathrm{F}_{\mathrm{S}} \mid$ maksimal dengan nilai tabel Kolmogorov Smirnov. Berdasarkan tabel Kolmogorov Smirnov diperoleh nilai 0,126 , dengan demikian $0,018<0,126$ maka $\mathrm{H}_{0}$ diterima, sehingga dapat disimpulkan bahwa nilai residual $\mathrm{X} 1$ terhadap $\mathrm{Y}$ atau nilai residual bimbingan belajar dari orang tua terhadap kompetensi pengetahuan IPS berdistribusi normal. Selanjutnya Berdasarkan hasil perhitungan, diperoleh nilai $\left|\mathrm{F}_{\mathrm{T}}-\mathrm{F}_{\mathrm{S}}\right|$ maksimal pada data residual $\mathrm{X} 2$ terhadap $\mathrm{Y}$ adalah 0,0395 . Selanjutnya yaitu membandingkan hasil $\left|\mathrm{F}_{\mathrm{T}} \mathrm{F}_{\mathrm{S}}\right|$ maksimal dengan nilai tabel Kolmogorov Smirnov. Berdasarkan tabel Kolmogorov Smirnov diperoleh nilai 0,126, dengan demikian $0,0395<0,126$ maka $\mathrm{H}_{0}$ diterima, sehingga dapat disimpulkan bahwa nilai residual $\mathrm{X} 2$ terhadap $Y$ atau nilai residual motivasi berprestasi terhadap kompetensi pengetahuan IPS berdistribusi normal. Selanjutnya Berdasarkan hasil perhitungan, diperoleh nilai $\mid F_{T^{-}}$ $F_{S} \mid$ maksimal pada data residual $X 1, X 2$ terhadap $Y$ adalah 0,058 . Selanjutnya yaitu membandingkan hasil $\left|\mathrm{F}_{\mathrm{T}}-\mathrm{F}_{\mathrm{S}}\right|$ maksimal dengan nilai tabel Kolmogorov Smirnov. Berdasarkan tabel Kolmogorov Smirnov diperoleh nilai 0,126, dengan demikian 0,058 < 0,126 maka $\mathrm{H}_{0}$ diterima, sehingga dapat disimpulkan bahwa nilai residual $\mathrm{X} 1, \mathrm{X} 2$ terhadap $\mathrm{Y}$ atau nilai residual bimbingan belajar dari orang tua dan motivasi berprestasi terhadap kompetensi pengetahuan IPS berdistribusi normal.

Pengujian linearitas juga dilakukan dan dari hasil yang didapatkan harga $F_{\text {hit }}=1,31<F_{\text {tabel }}$ $=1,55$ dapat disimpulkan bahwa data $X 1$ terhadap $Y$ bersifat linear. Selanjutnya Dari hasil yang didapatkan harga $F_{\text {hit }}=-1,63<F_{\text {tabel }}=1,55$ dapat disimpulkan bahwa data $\mathrm{X} 2$ terhadap $\mathrm{Y}$ bersifat linear.

Uji Multikolinieritas untuk mengetahui hubungan linear antar variabel independen dalam sebuah model regresi. Uji multikolinieritas dilakukan dengan melihat nilai Variance Inflation Factor (VIF) dan Collinierity Tolerance. Metode regresi dianggap baik jika nilai Variance Inflation Factor (VIF) dibawah $10(\leq 10)$ dan nilai Collinierity Tolerance diatas 0,1 $(\geq 0,1)$. Pada hasil yang telah dipaparkan dan dapat disimpulkan bahwa tidak terjadi multikolinieritas dikarenakan Tol 0,88 > 0,1 dan VIF $1,13<10$.

Uji Heterokedastisidas merupakan uji untuk mengetahui apakah dalam sebuah model regresi dalam penelitian, terjadi ketidaksamaan varian dari residual yang diamati. Menurut Ismail (2018:220) "apabila varian yang diamati bersifat tetap atau ajeg, keadaan ini disebut sebagai homokedastisidas. Sebaliknya jika varian yang diamati berubah dari satu pengamatan dengan pengamatan lain, kondisi data disebut heterokedastisidas". (Ismail, 2018). Berikut merupakan hasil dari pengujian heterokedastisidas.

Tabel 04

Hasil dari Pengujian Heterokedastisidas.

\begin{tabular}{|c|c|c|c|c|c|c|}
\hline \multirow[t]{2}{*}{ Model } & & \multicolumn{2}{|c|}{$\begin{array}{l}\text { Unstandardized } \\
\text { Coefficients }\end{array}$} & \multirow{2}{*}{$\begin{array}{c}\text { Standardized } \\
\text { Coefficients } \\
\text { Beta }\end{array}$} & \multirow{2}{*}{$\begin{array}{l}\mathbf{t} \\
\mathrm{B}\end{array}$} & \multirow{2}{*}{$\begin{array}{l}\text { Sig. } \\
\text { Std. } \\
\text { Error }\end{array}$} \\
\hline & & B & Error & & & \\
\hline \multirow{3}{*}{1} & (Constant) & .672 & 2.496 & & .269 & .788 \\
\hline & $\mathrm{X} 1$ & .020 & .023 & .085 & .869 & .387 \\
\hline & $\mathrm{X} 2$ & .005 & .020 & .027 & .275 & .784 \\
\hline
\end{tabular}

Uji statistik yang dapat digunakan untuk menguji heteroskedastisitas adalah uji Glejser berbantuan aplikasi Spss 21.0. Pada model regresi yang baik, tidak akan terjadi heterokedastisidas apabila nilai signifikansinya $(\rho)>0,05$. Berdasarkan hasil uji heterokedastisidas data penelitian pada tabel, dapat dilihat nilai signifikansinya pada variabel peran orang tua dan motivasi belajar terhadap kompetensi pengetahuan matematika secara 
berturut-turut adalah 0,387 dan $0,784(\rho>0,05)$. Dapat disimpulkan bahwa tidak terjadi heterokedastisidas pada model regresi dalam penelitian ini.

Pengujian hipotesis dapat dilakukan apabila telah memenuhi empat uji asumsi yang telah dilakukan. Uji hipotesis dilakukan dengan menggunakan teknik analisis regresi linear sederhana untuk menguji hipotesis 1 dan 2 dan analisis regresi linear berganda untuk menguji hipotesis 3. Adapun hipotesis yang diuji adalah hipotesis nol $\left(\mathrm{H}_{0}\right)$.

Berdasarkan hasil analisis untuk hasil pengujian hipotesis pertama didapatkan $F_{\text {reg }}$ sebesar $=115$ dan $F_{\text {tabel }}$ sebesar 3,92 sehingga $\mathrm{Ho}$ ditolak, diketahui bahwa $F_{\text {reg }}>F_{\text {tabel. }}$. Dapat disimpulkan bahwa bimbingan belajar dari orang tua mempunyai pengaruh yang signifikan terhadap kompetensi pengetahuan IPS siswa kelas IV SD Gusus VII Mengwi. Hasil analisis untuk hasil pengujian hipotesis kedua didapatkan $F_{\text {reg }}$ sebesar $=115$ dan $F_{\text {tabel }}$ sebesar 3,92 sehingga Ho ditolak, diketahui bahwa $F_{\text {reg }}>F_{\text {tabel. }}$. Dapat disimpulkan bahwa motivasi berprestasi mempunyai pengaruh yang signifikan terhadap kompetensi pengetahuan IPS siswa kelas IV SD Gugus VII Mengwi. Hasil analisis untuk hasil pengujian hipotesis ketiga didapatkan $F_{\text {reg }}$ sebesar $=17,81$ dan $F_{\text {tabel }}$ sebesar 3,08 sehingga $\mathrm{Ho}$ ditolak, diketahui bahwa $F_{\text {reg }}>F_{\text {tabel. }}$. Dapat disimpulkan bahwa bimbingan belajar dari orang tua dan motivasi berprestasi mempunyai pengaruh yang signifikan terhadap kompetensi pengetahuan IPS siswa kelas IV SD Gugus VII Mengwi Tahun Ajaran 2018/2019.

Kontribusi dalam penelitian ini dapat dinyatakan bahwa besarnya sumbangan bimbingan belajar dari orang tua terhadap kompetensi pengetauan IPS sebesar 12,25\%, motivasi berprestasi terhadap kompetensi pengetahuan IPS sebesar 19,36\%, sedangkan sumbangan bersama-sama bimbingan belajar dari orang tua dan motivasi berprestasi terhadap kompetensi pengetahuan IPS sebesar $24,01 \%$, selebihnya disumbangkan oleh faktor lain yang tidak diteliti.

\section{Simpulan dan Saran}

Berdasarkan hasil penelitian dan analisis data statistik, maka diperoleh kesimpulan 1) terdapat pengaruh yang signifikan bimbingan belajar dari orang tua terhadap kompetensi pengetahuan IPS siswa kelas IV SD Gusus VII Mengwi tahun ajaran 2018/2019. Hal ini berarti, semakin tinggi tingkat bimbingan belajar dari orang tua maka semakin tinggi kompetensi pengetahuan IPS siswa. 2) terdapat pengaruh yang signifikan motivasi berprestasi terhadap kompetensi pengetahuan IPS siswa kelas IV SD Gugus VII Mengwi tahun ajaran 2018/2019. Hal ini berarti, semakin tinggi motivasi belajar berprestasi siswa maka semakin tinggi kompetensi pengetahuan IPS siswa. 3) terdapat pengaruh yang signifikan bimbingan belajar dari orang tua dan motivasi berprestasi terhadap kompetensi pengetahuan IPS siswa kelas IV SD Gugus VII Mengwi Tahun Ajaran 2018/2019. Hal ini berarti, semakin tinggi tingkat bimbingan belajar orang tua dan motivasi berprestasi siswa maka semakin tinggi kompetensi pengetahuan IPS siswa.

Berdasarkan simpulan yang telah dipaparkan maka dapat disampaikan saran-saran sebagai berikut. 1) Kepada Guru diharapkan meningkatkan kerja sama dengan pihak orang tua dalam rangka memberikan bimbingan belajar secara terarah baik di sekolah maupun di rumah. Bimbingan belajar tersebut meliputi mengarahkan cara belajar, menentukan waktu belajar, membantu mengatasi kesulitan belajar, menyediakan fasilitas belajar, memberikan motivasi belajar, dan membentuk kebiasaan belajar. 2) Kepada Sekolah diharapkan dapat mengupayakan untuk merancang program FGD (Focus Group Discussion) dalam rangka bekerja sama dengan pihak orang tua peserta didik untuk melakukan bimbingan belajar selama di rumah karena bimbingan belajar orang tua telah terbukti efektif sebagai usaha meningkatkan pencapaian hasil belajar IPS peserta didik. 3) Kepada peneliti lain diharapkan agar hasil penelitian ini digunakan sebagai referensi untuk melaksanakan penelitian selanjutnya. 


\section{Daftar Pustaka}

Agung, A.A.G. 2014. Metodologi Penelitian Pendidikan. Malang : Aditya Media Publishing.

Aisyah, Siti. 2015. Perkembangan Peserta Didik dan Bimbingan Belajar. Yogyakarta : Deeppublish.

Arikunto, Suharsimi. 2002. Dasar-dasar Evaluasi Pendidikan. Jakarta : Bumi Aksara.

Badan Standar Nasional Pendidikan, 2006. Standar Isi Untuk Satuan Pendidikan Dasar dan Menengah : Jakarta.

Cahyono, Tri. 2015. Statistik Uji Normalitas. Purwokerto. Yasamas.

Dantes, Nyoman. 2012. Metode Penelitian. Yogyakarta : Andi.

Dantes, Nyoman. 2016. Metode Penelitian. Yogyakarta: Andi.

Darmadi, H. 2017. Pengembangan Model Dan Metode Pembelajaran Dalam Dinamika Belajar Siswa. Yogyakarta : Deeoublish.

Dimyati dan Mudjiono. 2015. Belajar dan Pembelajaran. Jakarta : PT Rineka Cipta.

Djaali, H. 2008. Psikologi Pendidikan. Jakarta : PT Bumi Aksara.

Fernando. 2014. Hubungan Antara Perhatian Orang Tua dan Motivasi Berprestasi dengan Prestasi Belajar Kompetensi Keahlian Animasi Siswa Kelas XI SMK Negeri 3 Kasihan. Yogyakarta : Univesrsitas Negeri Yogyakarta.

Gunarsa, D. 1984. Psikologi Untuk Keluarga. Jakarta : PT BPK Gunung Mulia.

Hamalik, Oemar. 2017. Psikologi Belajar dan Mengajar. Bandung : Sinar Baru Algensindo.

Hasbullah. 2009. Dasar - Dasar Ilmu Pendidikan. Jakarta : PT Rajagrafindo Persada.

Ismail, Fajri. 2018. Statistika Untuk penelitian Pendidikan dan IImu-ilmu Sosial. Jakarta: Prenadamedia Group.

Mulyadi, Seto, dkk. 2016. Psikologi Pendidikan dengan Pendekatan Teori-teori Baru dalam Psikologi. Cetakan Ke-1. Jakarta : PT Rajagrafindo Persada.

Mulyasa, E. 2006. Kurikulum Berbasis Kompetensi Konsep, Karakteristik, Implmentasi, dan Inovasi. Cetakan Ke-9. Bandung : PT Remaja Rosdakarya Offset.

Permendikbud. 2016. Salinan Peraturan Menteri Pendidikan Dan Kebudayaan Republik Indonesia Nomor 24 Tahun 2016 Tentang Kompetensi Inti Dan Kompetensi Dasar Pelajaran Pada Kurikulum 2013 Pada Pendidikan Dasar Dan Pendidikan Menengah.

Sanjaya, Wina. 2008. Pembelajaran dalam Implementasi Kurikulum Berbasis Kompetensi. Cetakan Ke-3. Jakarta : Kencana Prenada Media Grup. 
Septiana, Prisca. 2016. Hubungan Bimbingan Belajar Orang Tua Dengan Hasil Belajar IPS Peserta Didik Kelas V SDN Gugus Erlangga Kecamatan Pecangaan Kabupaten Jepara. Semarang : Universitas Negeri Semarang.

Setyosari, H, Punaji. 2012. Metode Penelitian Prndidikan dan Pengembangan. Jakarta : Kharisma Putra Utama.

Siregar, Syofian. 2017. Metode Penelitian Kuantitatif. Jakarta: Kencana.

Slameto. 2003. Belajar dan Faktr-faktor yang Mempengeruhinya. Jakarta : PT Rineka Cipta.

Slameto. 2010. Belajar dan Faktr-faktor yang Mempengeruhinya. Jakarta : PT Rineka Cipta..

Sugiyono. 2012. Metode Penelitian Kuantitatif, Kualitatif, Dan R\&D. Bandung: Alfabeta.

Sugiyono. 2013. Statistika Untuk Penelitian. Bandung : Alfabeta.

Sugiyono. 2015. Metode Penelitian Pendidikan. Bandung : Alfabeta

Sujanto, Agus. 2014. Psikologi Kepribadian. Jakarta : Bumi Aksara.

Sukardi. 2012. Metodologi Penelitian Pendidikan. Cetakan Ke-6. Jakarta: Bumi Aksara.

Sukini. 2016. Menjadi Diri Sendiri. Yogyakarta : Istana Media.

Supardi, U.S. 2013. Aplikasi Statistika dalam Penelitian Konsep Statistika yang Lebih Komprehensif. Jakarta : Change Publication.

Suprihatiningrum, Jamil. 2016. Strategi Pembelajaran. Yogyakarta : Ar-Ruzz Media.

Susanto, Ahmad. 2013. Teori Belajar dan Pembelajaran di Sekolah Dasar. Jakarta : Kencana Prenadamwdia Group.

Susanto, Ahmad. 2017. Bimbingan dan Konseling di Sekolah. Jakarta : Prenadamedia Group.

Susanto, Ahmad. 2018. Bimbingan dan Konseling di Sekolah. Jakarta : Prenadamedia Group.

Syamsu Yusuf dan Sugandhi. 2013. Perkembangan Peserta Didik Mata Kuliah Dasar Profesi (MKDP) Bagi Para Mahasiswa Calon Guru di Lembaga Pendidikan Tenaga Kependidikan. Jakarta : PT Rajagrafindo Persada.

Thobroni. 2015. Belajar \& Pembelajaran. Yogyakarta. Ar-Ruzz Media.

Undang-Undang Republik Indonesia No. 20 Tahun 2003 tentang Sistem Pendidikan Nasional. 2003. Jakarta : Kementrian Pendidikan Nasional.

Winarsunu,Tulus.2002.Statistik dalam Penelitian Psikologi dan Pendidikan. Malang: UMM Press

Yusuf, A, Muri. 2015. Asesmen dan Evaluasi Pendidikan. Jakarta : Prenandamedia Group. 